\title{
Zombory-Moldován, Béla. 2014. The Burning of the World - $A$ Memoir of 1914 (trans. Peter Zombory-Moldovan). New York: New York Review of Books. 155 pp. Illus.
}

\section{Reviewed by Judit Kádár, University of West Hungary}

The world War I memoir of Hungarian painter Béla Zombory-Moldován (1885-1967), published on the one-hundredth anniversary of the outbreak of the war, offers another proof that the Eastern-European region of Galicia could have been rightly named "Bloodlands" (a term coined by American historian Timothy Snyder) well before the WWII mass murders committed there by the totalitarian regimes of Stalin and Hitler. Only one-third of the book depicts the author's service in the Austro-Hungarian army in World War I, the military deployment of his regiment and mainly their frontline combats; yet, the poignant, insightful descriptions of the careless treatment of privates injured and dying in the battlefield, besides horrifying the reader, in fact add up to the claim that it was principally the indifference of the Austro-Hungarian army commanders to human life that led to the mass deaths of their own soldiers in the remote locations of the Eastern Front. The specific time of writing of Zombory-Moldován's memoir is uncertain: according to Peter Zombory-Moldovan, the author's grandson and English translator of his manuscript who added an introduction including a concise history of Hungary in the first half of the twentieth century and a short biography of his grandfather, the memoir was most likely written a few years after 1946. At that time the communist regime dismissed the painter from the Budapest School of Applied Arts, where he had been the Principal since 1935, and whereupon he secluded himself up in his summer house at Balatonfüred by Lake Balaton.

Zombory-Moldován's book is informative about the deadly experiences of soldiers in World War I but is also interspersed with antisemitism in the form of jokes and reflections on Jewish soldiers and more generally on Hungary of his time. While in service, when faced with extreme difficulties, the author and other unit commanders routinely ordered one of the soldiers in their platoon to tell jokes to lighten the mood and, incidentally or not, all of the five jokes recalled in this memoir make fun of Jews. Three of these jokes are recited during a two-day long exhaustive march of the regiment from Veszprém, where they reported for duty, to the railway station of Tapolca, fifty kilometers to the southwest; the fourth is shared by the men while awaiting further commands in the firing lines of the lost battle of Rava-Ruska, with dying comrades and headless corpses scattered around them; the fifth, a word game, is recounted by the narrator himself just after being repatriated to Budapest following his injury in the battlefield. Four out of the five jokes are based on anti-Semitic stereotypes commonly referred to at the time about the excessive sexuality or the foolishness of the Jews, but the fifth already bears the marks of the postwar tendency to accuse the Jews of the defeat. This exchange, "Cohen meets Weiss. 'So how are you?' 'Exemptionally well!'” (90), implies that during the war the cunning Jews managed to avoid service in the army. Apparently, the frustrated painter who, while convalescing

$($ (c) $)$ EY

ULIS D-Senk 
Kádár, Judit. “Zombory-Moldován, Béla. 2014. The Burning of the World - A Memoir of 1914 (trans. Peter Zombory-Moldovan). New York: New York Review of Books. 155 pp. Illus.” Hungarian Cultural Studies. eJournal of the American Hungarian Educators Association, Volume 9 (2016): http://ahea.pitt.edu DOI: 10.5195/ahea.2016.235

in Budapest, experienced the general indifference of the city dwellers of whichever denomination toward the war directed his anger at the Jews specifically.

From another angle altogether, these anti-Jewish jokes show that it was the hatred of Jews that helped to keep the reluctant battalion together, because none of the soldiers, Jews or Christians, really wanted to be there. In his introduction to The Burning of the World, Peter Zombory-Moldovan considers what he terms his grandfather's "faint disdain [for Jews] characteristic of his class and age" (xiv). This "disdain" is not astonishing at all: the fragments of information extracted from the memoir and from the grandson's introduction suggest that Béla Zombory-Moldován, who was most probably born into an underprivileged gentry family in Munkács, presently Mukačevo in western Ukraine and at that time a far-flung region of the Kingdom of Hungary bordering Austrian-ruled Galicia, made every effort to get into the Hungarian ruling classes that strongly looked down on minorities. At the outbreak of the war he was barely at the start of a promising career, so no wonder that he sought to identify himself with the values and norms of the ruling elite. Even before the war, the young painter had earned his living by sending illustrations to Dörmögö Dömötör, a weekly for children issued by the Singer and Wolfner Publishing House, whose wide range of magazines supported and propagated the official ideology of the governing elite; and he had also been employed by the Budapest School of Applied Arts as a teacher. No wonder, then, that he expressed his dislike of modern tendencies in art, including those exemplified in the poetry of Endre Ady, whose philosemitism and critical stance toward the regime equally irritated the ruling classes (73).

Zombory-Moldován's work could be more profitably read in the context of other writings on World War I by other flesh witnesses, and a number of these are presently available but unfortunately only in Hungarian. See, for example, the war diary by Béla Balázs, a Jewish writer, librettist and film critic who served in Serbia, concerning the same war period, titled Lelkek a háborúban. Balázs Béla honvédtizedes naplója ['Souls in the War - the Diary of Infantry Corporal Béla Balázs'] (Gyoma: Kner Izidor Kiadása: 1916; readable online at: https://archive.org/stream/llekhboruban00baluoft/llekhboruban00baluoft_djvu.txt). Unlike Zombory-Moldován, the young Balázs, who had by then already gained some fame by his libretto of Béla Bartók's operetta Bluebeard's Castle, had been judged untauglich ['unfit'] for military service, but he nevertheless volunteered for the front. It is possible that Balázs's diary may have been known to Zombory-Moldován, who joined the army reluctantly, but obviously the book did not affect his views concerning the participation of Jews in the war. The journalist and painter Margit Vészi (1885-1961) and the writer and dramatist Ferenc Molnár (1878-1952) also published each a volume describing the fronts they visited as war correspondents. Vészi's Az égö Európa ['Europe Burning,' 1915] has not been reissued yet, but Molnár's Egy haditudósító emlékei ['Reflections of a War Correspondent,' 1916] had a second edition by Pallas Stúdió in 2000. Consider also the very recently published World War I diary and letters of Jenő Kornis (1883-1944), a Jewish Budapest bank clerk who was taken prisoner by the Russians at Przmyśl, titled A barna táska. Egy hadifogoly naplója és levelezése 1914-1918 ['The Brown Briefcase - the Diary and Correspondence of a Prisoner of War 1914-1918'] (Budapest: Noran Libro Kiadó, 2015). 
Finally, it is Israeli writer and poet Avigdor Hameiri (1890-1970) who recounts most at length about the horrors of World War I for the Hungarian soldiers, the miserable poverty of civilians in Carpathian-Ruthenia and Galicia, and about the pervasive anti-Semitism he confronted. Born Avigdor Feuerstein in a small village near Munkács he was conscripted into the Hungarian Army in 1914 and became a commissioned officer. For approximately two years he served in Galicia, was captured by the Russians in 1916 and freed in 1917 due to the Russian Revolution. In his Hebrew memoir/documentary novel Hashigaon Hagadol (1929), which appeared in English as The Great Madness (New York: Vantage Press, 1952), but, ironically, in Hungarian only in 2009 (János Kőbányai, ed. A nagy örület. Budapest: Múlt és Jövő), Hameiri also describes Jewish heroism that belies the traditional stereotypes of cowardly Jews. Moreover, he specifically discusses the shared patriotism of Jewish soldiers and other Habsburg subjects in the war in 1914.

Due to Zombory-Moldován's mentality as inadvertently revealed in the memoir, his book can be seen as an enlightening read not only for scholars and students inquiring into the events of the Galician campaign of August and September of 1914, but also for researchers and hopefully broader audiences interested in the role of historical context in identity formation and in majority-minority relations in the last years of the Austro-Hungarian Monarchy. However, it is regrettable that Zombory-Moldován's book has not been published in Hungarian yet, and that most of the other diaries and recollections written by Hungarian participants of the war are not available in English, as the joint consideration of these accounts and others would provide a more complete picture of the destiny of the Habsburg Monarchy and of Hungary following the catastrophic war. 